\title{
Study Clastic Sediments and Evaporite Deposits' Changes in the Sedimentary Core Lake Maharlou, Iran
}

\author{
Abdolah Safe ${ }^{1}$, Fatemeh Sabokkhiz ${ }^{1}$, Mohamad Hosein Ramesht ${ }^{1}$, Morteza Djamali ${ }^{2,3}$ \& Abdolmajid Naderi \\ Beni $^{3}$ \\ ${ }^{1}$ Geography Since and planning Faculty, University of Isfahan, Isfahan, Iran \\ ${ }^{2}$ Institute Me'diterrane'en d'Ecologie et de Pale'oe'cologie, France \\ ${ }^{3}$ Iranian National Institute for Oceanography \& Atmospheric Science, Iran \\ Correspondence: Abdolah Safe, Geography Since and planning Faculty, University of Isfahan, Isfahan, Iran. Tel: \\ 98-9133-009-597. E-mail: sabokkhiz.f@gmail.com
}

Received: November 16, 2015

Accepted: November 25, $2015 \quad$ Online Published: January 13, 2016

doi:10.5539/mas.v10n4p1

URL: http://dx.doi.org/10.5539/mas.v10n4p1

\begin{abstract}
The continental environments, lakes are proper for deposition locations of evaporites. Evaporite minerals are formed wherever the evaporation rate is more than incoming water to the basin. In this article the evaporate deposits (Calcite, Gypsum and Halite) are studied in a sedimentary core of Lake Maharlou, Zagros Mountains, South of Iran. The core sample treated for getting Magnetic Susceptibility values along with the core as well as basic sedimentological data including grain size, Total Organic Matter and carbonate contents. $\mathrm{NaCl}$ is determin ed by gravimetric analysis. Loss on Ignition is applied to measure and estimate the amount of (OC), (Ca) and (SO4) mineralogy of which is determined by SEM method. The exists a direct relation between evaporation deposit formation of lake water level reduction. Accordingly, the change in the sediment stratum indicating the level of evaporations. The results indicate a lower extant of gypsum than $\mathrm{Ca}$ and $\mathrm{NaCl}$. The sequence of layers principle, changes in the shoreline (lake water level fluctuations) with respect to stratum zonation. Magnetic susceptibility level is directly related to the Silt layer thickness but also there is an indirect relation with the level of organically rich sediments' occurrence and abundance.
\end{abstract}

Keywords: evaporates, magnetic susceptibility, Maharlou Lake, zonation, clastic sediments

\section{Introduction}

There is a direct relationship in evaporative deposit with the changes in the depth of the lake. Therefore, valuable information is gained regarding the causation of changes in environment over time. Evaporite minerals formation is a natural phenomenon accruing in water-bodies containing deferent mineral.

Since sulfate is abundant in seawater and saline lakes, it is main component in evaporative minerals (Lewis \& McConchie, 1949). The age of sedimentary sulfates goes back to 3450 million years (Lambert et al., 1978).

Playa lake deposits even in small precipitation rates may cause major changes in lake-level, salinity and sedimentary records (Battarbee, 1999). The past changes in the hydrologic budget of basin could be determined through its sediments (Last, 1989). The studies of lacustrine sedimentology and geochemistry have become the center of attention due to their economic mineral resources and paleoenvironment information stored in their sediments (Rosen, 1994; Gierlowski \& Kelts, 1994; Valero et al., 1999). The sediments generated in present saline lakes and playas have been studied by numerous researchers in order to determine the paleoclimate (Spencer et al., 1984; Holliday et al., 1996; Crowley \& Hook, 1996; Li et al., 1996; Enzel \& Wells, 1997; Menking et al., 1997; Lowenstein et al., 1999; Sinha et al., 2006; Chao et al., 2009).

Playas are found in many parts of the world including Western US (Rosen, 1991), Australia (Bowler, 1986) and Iran (Krinsley, 1970). In Iran, the ancient evaporites are present in sedimentary records of three major horizons: (1) Hormoz series of Precambrian age; (2) Upper Jurassic deposits and (3) Tertiary evaporites (Darvishzadeh 1991; Rahimpour-Bonab and Alijani 2003; Rahimpour-Bonab and Kalantarzadeh 2005). The Tertiary evaporites are found mainly in the Zagros Basin and in the Central Iran (Rahimpour \& Kalantarzadeh, 2005; Rahimpour et al., 2007). In addition, Holocene evaporite deposits are widespread in numerous playas and lake/playas in various parts of Iran with different characteristics (e.g., Krinsley, 1972; Shahrabi, 1995; Farpoor \& Krouse, 2008; 
Farpoor et al., 2012). In his pioneering work, Krinsley (1970) studied morphology of surficial features of 60 playas within the interior of Iran. He determined characteristics, distribution, and development of the available playas. According to his findings, because the form and bedrock permeability of most of the Iranian basins have remained essentially stable since the late Pleistocene (Würm), subsequent hydrologic changes can be attributed to climatic changes.

In a study, on Late Pleistocene-Holocene by Khodakarami (2010) revealed the sediments of lake/playa Meyghan determine the sedimentological and mineralogical characteristics, to identify the brine evolution path and to determine the climatic variations in the area from its sedimentary records. Rahimpour-Bonab and Abdi (2012) with study on the lake/playa Meyghan Flowing water with low percentage of ions and $\mathrm{Na}-(\mathrm{Ca})-(\mathrm{Mg})-\mathrm{SO}_{4}-\mathrm{Cl}-$ $\left(\mathrm{CO}_{3}\right)$ types evolve, into a brine with high ions concentration during the geochemical evolution and mineral deposition. The geochemical evolution yields a $\mathrm{Na}-\mathrm{SO}_{4}-\mathrm{Cl}$ type brine.

While clastic components (calcite, quartz etc.) show on increasing trend in relation to depth, evaporites abundances show opposite trends. Furthermore, the average grain size of sediments increases with depth indicating higher energy in the past. This study evaluated clastic sediments and evaporite deposits' changes in the sedimentary core Maharlou lake by using physical and geochemical methods.

\section{Study Site (Physical Setting)}

The Hypersaline Lake, Maharlou is located in SW Iran with an area of $24910 \mathrm{~km}^{2}$ and $1.5 \mathrm{~m}$ depth. The lake lies about $20 \mathrm{~km}$ east of Shiraz at 1,455 m above sea level (masl) [Figure 1]. This lake is fed by direct precipitation and water inflow from surface run-offs, a few seasonal rivers and several karstic springs which compensate for the strong evaporation in a semi-arid climatic context (Dumas et al., 2003). The Maharlou catchment area consist of sedimentary rocks, mainly Precambrian diapiric evaporites associated with Mesozoic and Cenozoic limestone, sandstone, shale and dolomite formations. The formation of this lake goes back to the beginning of the Pleistocene because of its hydrogeological properties, past higher lake level stands and the survival of Pleistocene relict fish species (Krinsley, 1970; Dumas et al., 2003).

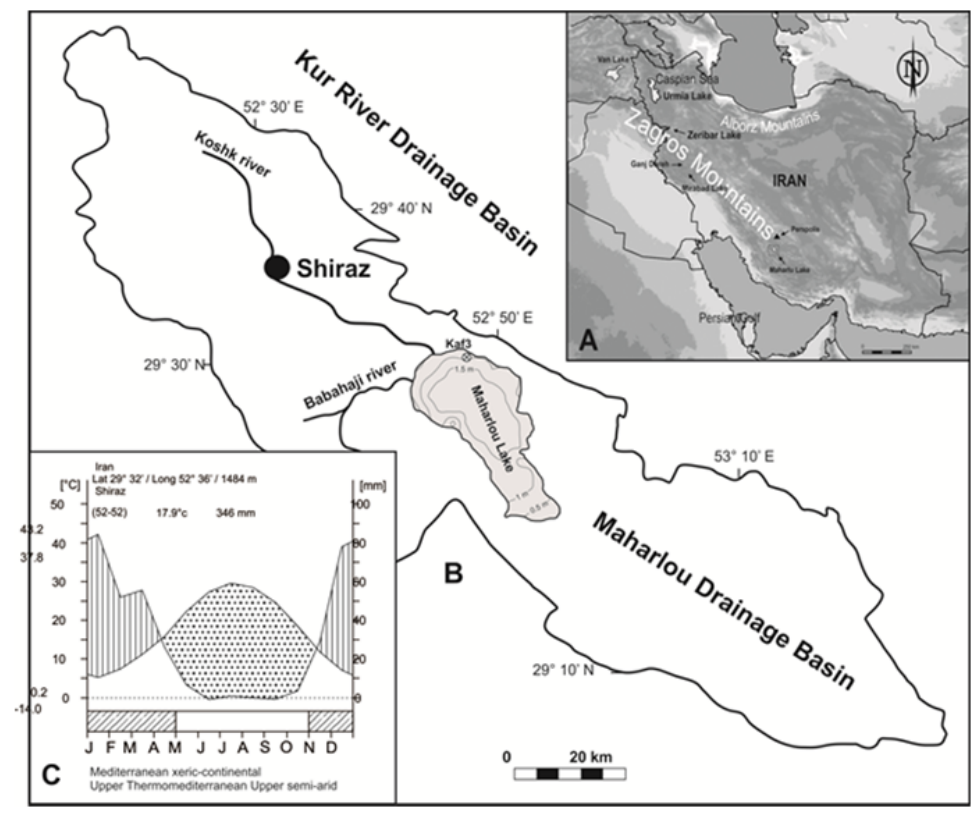

Figure 1. (A) Location of Lake Maharlou in SW Iran with the position of some other sites mentioned in the text, (B) its drainage basin limits and bathimetry and, (C) climate diagram for Shiraz, (modified form Djamali et al., 2008)

The climate of the Zagros Mountains, although showing great partial heterogeneity, is generally Mediterranean with a wet winter period and a hot dry summer (Blumler, 2008; Djamali et al., 2008). There are some variations in seasonality controlled by storm tracks and topography (Evans et al., 2004). In southern Iran, there is a positive correlation between the sea-surface temperatures of the Persian Gulf and rainfall (Nazemosadat \& Cordery, 2000). This indicates that despite the descending air in the Hadley cells corresponding to these latitudes, the 
Persian Gulf does has a slight role in controlling the climate of Southern Iran including the southern Zagros. Despite this fact, the extremely dry and hot climatic conditions of central Iran penetrate and modify the climate of the Eastern part of the Zagros. The climate diagram for Shiraz (20 km to the west of the lake, Figure 1(C)) matches a Mediterranean xeric-continental type of climate in the worldwide bioclimatic classification system (Rivas et al., 1997), with a mean annual temperature of $17.9^{\circ} \mathrm{C}$ and mean annual precipitation of $346 \mathrm{~mm}$. Dry season lasts for 7 months, from April to November. Maximum precipitation belongs to January with a very slight peak at the beginning of March.

\section{Materials and Methods}

The lake is examined through satellite imagery, tectonics and geological maps, related national and international reports and results optimized in previous studies. Two sediment cores were extracted using a Cobra TT Vibracorer.

Magnetic susceptibility measurement was made using a Bartington magnetic susceptibility meter with resolution of $2 \mathrm{~cm}$. A total of 88 subsamples were taken from a core based on consolidated method (facies change and systematic method) and were treated for grain size and basic sedimentological analysis. For grain size analysis, samples were prepared using $\mathrm{H}_{2} \mathrm{O}_{2}$ based on outlined methods of Carver (1971) and heated to remove organic materials (Santisteban et al quoted Dean, 2003). $\mathrm{NaCl}$ in the sediments measured from Bulk samples by flame photometric method. The amount of sand, silt and clay were calculated using a Horiba Laser particle Size Analyzer, LA-950. Gradistat software (Blott, 2000) was utilized to classify thesediments. The loss on ignition (LOI) introduction by Dean (1974) is applied to measure and estimate the amount of organic matter and carbonate mineral content in the sediments. The Gypsum content was determined based on Santisteban et al (2004) outlined method. SEM was implemented to identify the carbonate and gypsum mineralogy.

\section{Results and Interpretation}

\subsection{The Sediments and Magnetic Susceptibility Vertical Changes}

Generally, sediments of the Lake Maharlou are composed of chemical and clastic minerals that their portion in sediments changes inversely.

Based on the vertical changes of all the measured sedimentological and physical (magnetic susceptibility) variables, the core can be categorized into three major zones of $\mathrm{A}, \mathrm{B}$, and $\mathrm{C}$.

\subsubsection{Zone A}

In general, this zone $(533-270 \mathrm{Cm})$ is characterized by relatively high values of magnetic susceptibility at Depth $521(\mathrm{Cm})$ reaches its Maximum level $\left(1.5849 \mathrm{E}^{-04} \mathrm{~m}^{3} / \mathrm{Kg}\right.$, Table 1). This zone is distinguished by high trend line changes (10 degree, Figure 2). The dominantly silty zone contains laminates of sandy Silt (Figure 2).

Table 1. Magnetic Susceptibility changes along a $533 \mathrm{~cm}$ core of Maharlou Lake

\begin{tabular}{cccc}
\hline & $\begin{array}{c}\text { A Zone } \\
(533-270 \mathrm{Cm})\end{array}$ & $\begin{array}{c}\text { B Zone } \\
(270-80 \mathrm{Cm})\end{array}$ & $\begin{array}{c}\text { C Zone } \\
(80-0 \mathrm{Cm})\end{array}$ \\
\hline Maximum & $15.849 \mathrm{E}-05$ & $6.1679 \mathrm{E}-05$ & $2.8994 \mathrm{E}-05$ \\
Minimum & $0.19519 \mathrm{E}-05$ & $1.3575 \mathrm{E}-05$ & $2.6971 \mathrm{E}-05$ \\
Average & $5.10412 \mathrm{E}-05$ & $1.14286 \mathrm{E}-05$ & $1.24532 \mathrm{E}-05$ \\
\hline
\end{tabular}

\subsubsection{Zone B}

The zone is characterized by relatively lower values of Magnetic Susceptibility than Zone A (Table 1). Magnetic susceptibility in this zone has a Mean trend line change of 5 degree (Figure 2). The lithology mainly consists of silt whereas organic rich thin layers could be observed all along the zone. Three distinct peat layers are seen in 181- 183, 132 and $82-84 \mathrm{~cm}$ horizons. In addition, there is a dark silty sand layer in $140-155 \mathrm{~cm}$ horizon as well as an organic rich layer in depth of $165 \mathrm{~cm}$.

\subsubsection{Zone $\mathrm{C}$}

This zone is characterized by relatively low values of magnetic susceptibility (Table 1). Mean trend line is around 2.5 degree, with gentle slope of negative values (Figure 2).

The base of zone starts by a sand layer. However, the lithology of the zone is dominated by silt with some silty sand interlayers. Two layers of peats also could be seen in two horizons of 39 and $33 \mathrm{~cm}$. 


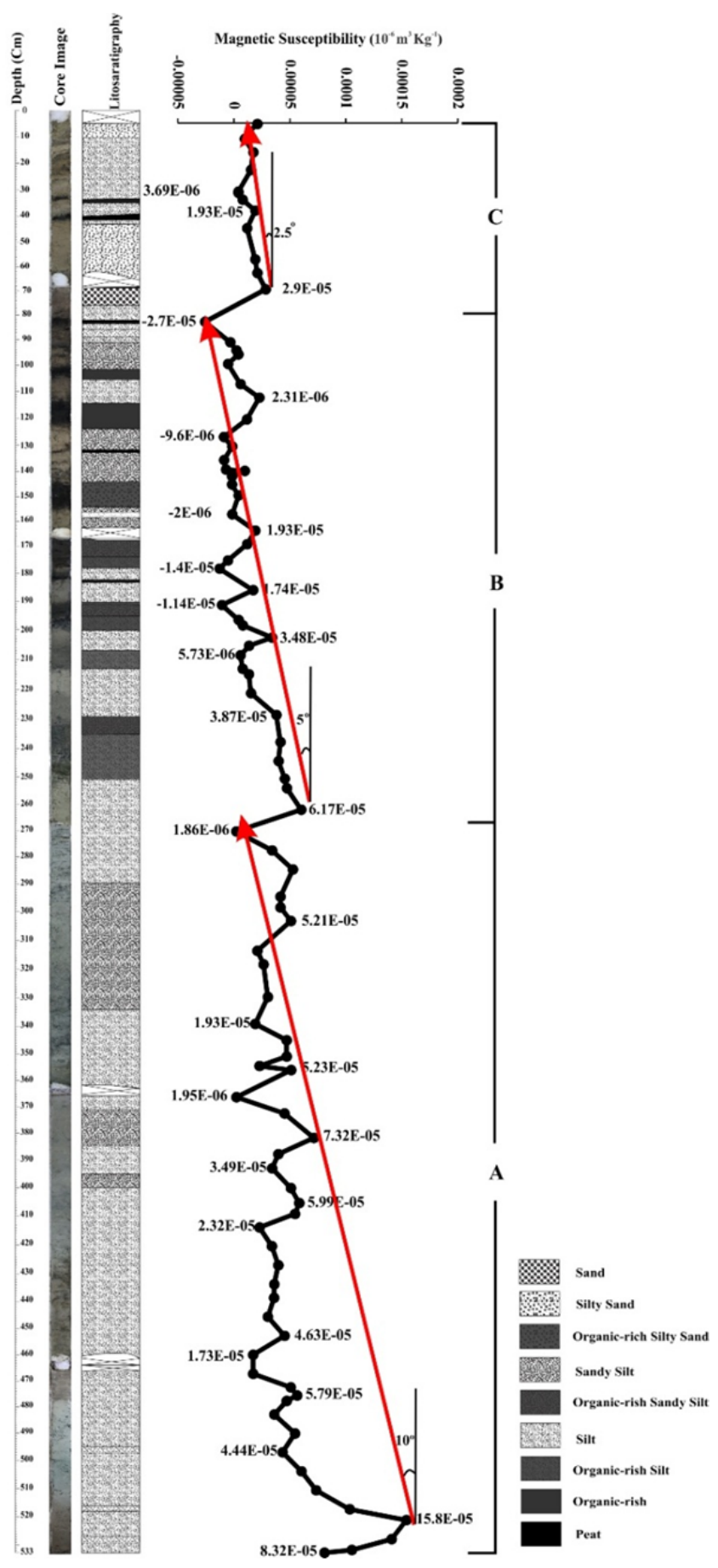

Figure 2. Classification of sediment core in lake Maharlou based on correlation of magnetic susceptibility, lithology and visual changes

\subsection{Evaporite Deposits}

Evaporite deposits are important part of saline lake sediments, which this describes study the findings from analysis of the lake sediments geochemistry and mineralogy. Mineralogy is a reliable tool for the study of evaporates; therefore subsamples are analyzed in this study by SEM (Figure 3). 


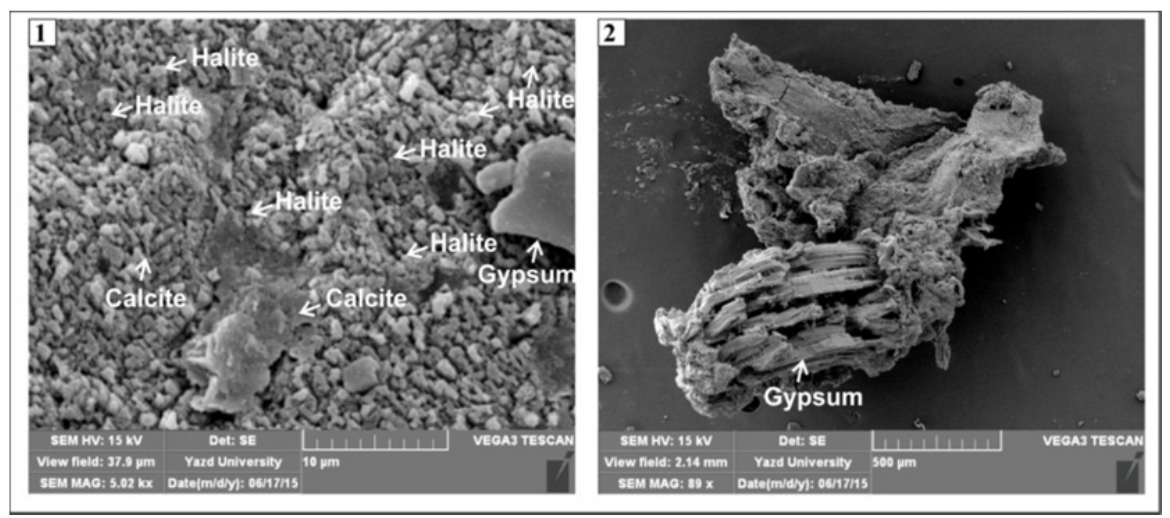

Figure 3. analyzed any subsamples by scanning electron microscope (SEM), In the no 1: indicate that Calcite $\left(\mathrm{CaCO}_{3}\right)$, Gypsum $\left(\mathrm{CaSo}_{4} \cdot 2 \mathrm{H}_{2} \mathrm{O}\right)$ and Halite minerals $(\mathrm{NaCl})$. In the $\mathrm{No} 2$ : Is growth Gypsum minerals on the Pieces of plant

According to radial growth of Halite and Gypsum minerals, it is evident that these minerals are formed on the lake floor, while rhombic shape of Calcite crystals indicates the detritus origin of Calcite (Figure4).
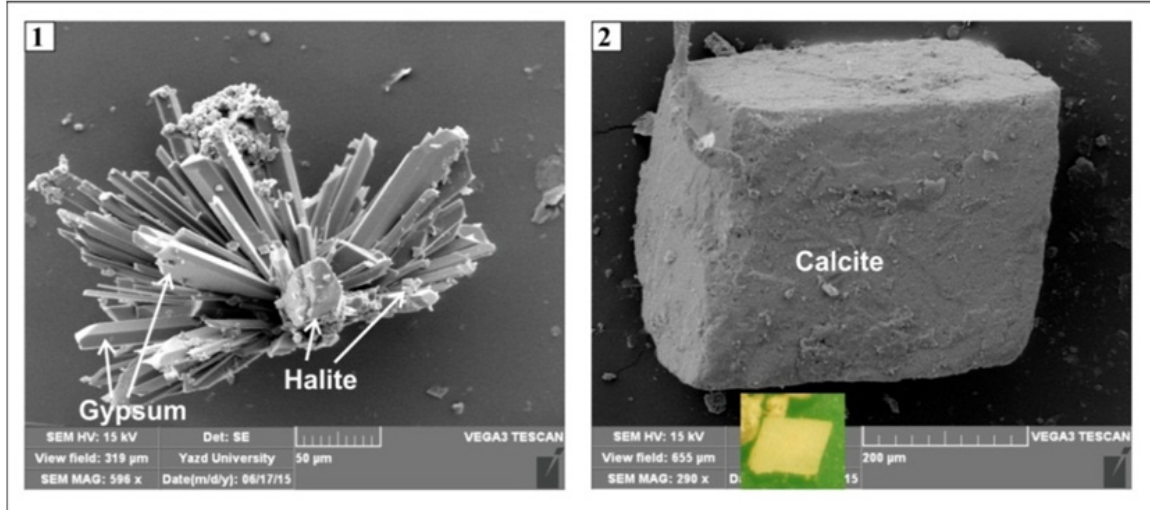

Figure 4. Scanning Electron Microscope pattern of Halite, Gypsum and Calcite in sediments of Maharlou Lake.

1) radial Gypsum mineral and growing Halite on it. 2) Rhombic Calcite mineral

\subsection{Geochemistry of Evaporites}

The content of evaporates changes dramatically in three mentioned zones of the sediment core (Table 2). According to changes in evaporates, zones could be divided into some subzones.

Table 2. Statistic data evaporate deposits $\left(\mathrm{NaCl}, \mathrm{SO}_{4}\right.$ and IC) and $\mathrm{OC}$ in $533(\mathrm{Cm})$ core of lake Maharlou

\begin{tabular}{ccccc}
\hline \multirow{2}{*}{ Name } & & $\begin{array}{r}\text { A Zone } \\
(533-270 \mathrm{Cm})\end{array}$ & $\begin{array}{c}\text { B Zone } \\
(270-80 \mathrm{Cm})\end{array}$ & $\begin{array}{c}\text { C Zone } \\
(80-0 \mathrm{Cm})\end{array}$ \\
\hline \multirow{2}{*}{$\mathrm{NaCl}(\%)$} & Maximum & 42.70 & 42.70 & 24.77 \\
(Density) & Minimum & 3.94 & 5.04 & 2.96 \\
& Average & 11.93 & 15.14 & 7 \\
$\mathrm{SO} 4(\%)$ & Maximum & 2.89 & 1.09 & 0.19 \\
$(\mathrm{LOI})$ & Minimum & 0.002 & 0 & 0.05 \\
& Average & 0.48 & 0.11 & 0.14 \\
$\mathrm{IC}(\%)$ & Maximum & 9.049 & 12.22 & 8.52 \\
$(\mathrm{LOI})$ & Minimum & 0.19 & 0.14 & 1.31 \\
OC (\%) & Average & 2.19 & 5.60 & 4 \\
\hline
\end{tabular}




\begin{tabular}{ccccc}
\hline (LOI) & Minimum & 0 & 0.51 & 1.29 \\
& Average & 8.01 & 4.26 & 4.89 \\
\hline
\end{tabular}

\subsubsection{Zone A}

The zone is characterized by relatively low and constant values of total organic carbon (OC) and relatively low and low fluctuating values of $\mathrm{NaCl}$.

Subzone A1. The outstanding feature of this subzone is the presence of the highest peak of magnetic susceptibility in the whole core $\left(15.849 \mathrm{E}-05 \mathrm{~m}^{3} \mathrm{Kg}^{-1}\right)$. There exist almost no sulfate carbonates or gypsum $\left(\mathrm{SO}_{4}\right)$ and inorganic carbon (IC) ranges between 7 to $30 \%$ (Figure 5). Sediment composition is dominated by silt with extremely low values of sand and clay. The corresponding lithology of this subzone is calcareous silt and sandy silt with greenish Gray to greenish Brown color.

Subzone A2. Physiochemical factors of the sediments significantly change at the beginning of this subzone. The most obvious change is the sudden appearance and increase of sulfate which represents the fluctuations during the deposition of this subzone (Figure 5). Maximum value of sulfate content reaches up to $2.89 \%$. IC shows some fluctuations between $8 \%$ to $0.1 \%$. OC content is higher than that in subzone A1 and remains relatively constant around $10 \%$.

Subzone A3. Most of the physiochemical features of the sediments change significantly at the beginning of this subzone. Lower amount of sulfate represents a minimum fluctuations during the deposition of this subzone (figure 5). The values of Calcium sulfate content range between $0.16 \%-0 \%$. IC also shows some fluctuations between $4.16 \%-1.3 \%$. The OC amount is higher compare to subzone $\mathrm{A} 1$ and oscillates between $10 \%-3 \%$.

\subsubsection{Zone B}

Generally, the zone shows high fluctuations in values of $\mathrm{NaCl}$, IC and OC. All these physiochemical features are in a sharp contrast compared to zone $\mathrm{C}$.

Subzone B1. The most outstanding feature of this subzone is the presence of the highest peaks of $\mathrm{NaCl}(35 \%$ and $13 \%)$. Almost, there is not any gypsum crystal in this subzone. The IC content changes between $7.5 \%$ and $5 \%$ (Figure 5). As zone A, the sediments are dominated by silt with extremely low values of sand and clay. The corresponding lithology to this subzone is calcareous silt with greenish gray color, organic rich silt and sandy silt and organic rich sandy silt with very dark gray to black color.

Subzone B2. While this subzone shows low magnetic susceptibility values, halite content reaches up to $40 \%$. The gypsum crystals (CaSO4) content is as low as (1.9\%) (Figure 5). IC generates two peaks of $6 \%$ and $2.5 \%$. The sediments are dominated by silt with extremely low values of sand and clay. The corresponding lithology for this subzone is calcareous silt with greenish Gray, dark greenish Gray to black color.

\subsubsection{Zone $\mathrm{C}$}

Around $4 \%$ of sulfate could be found in this subzone, whereas IC varies around $10 \%$ to $0.1 \%$ and OC oscillates between $3 \%$ to $5 \%$.

Generally, three major trends could be identified in zone C: (1). low content of $\mathrm{NaCl}$ as well as IC and high content of OC; 2) high content of $\mathrm{NaCl}$ and IC and low content of OC; 3) high content of $\mathrm{NaCl}$, low content of IC and high content of OC. In this zone calcium sulfate content is too small to detect. 


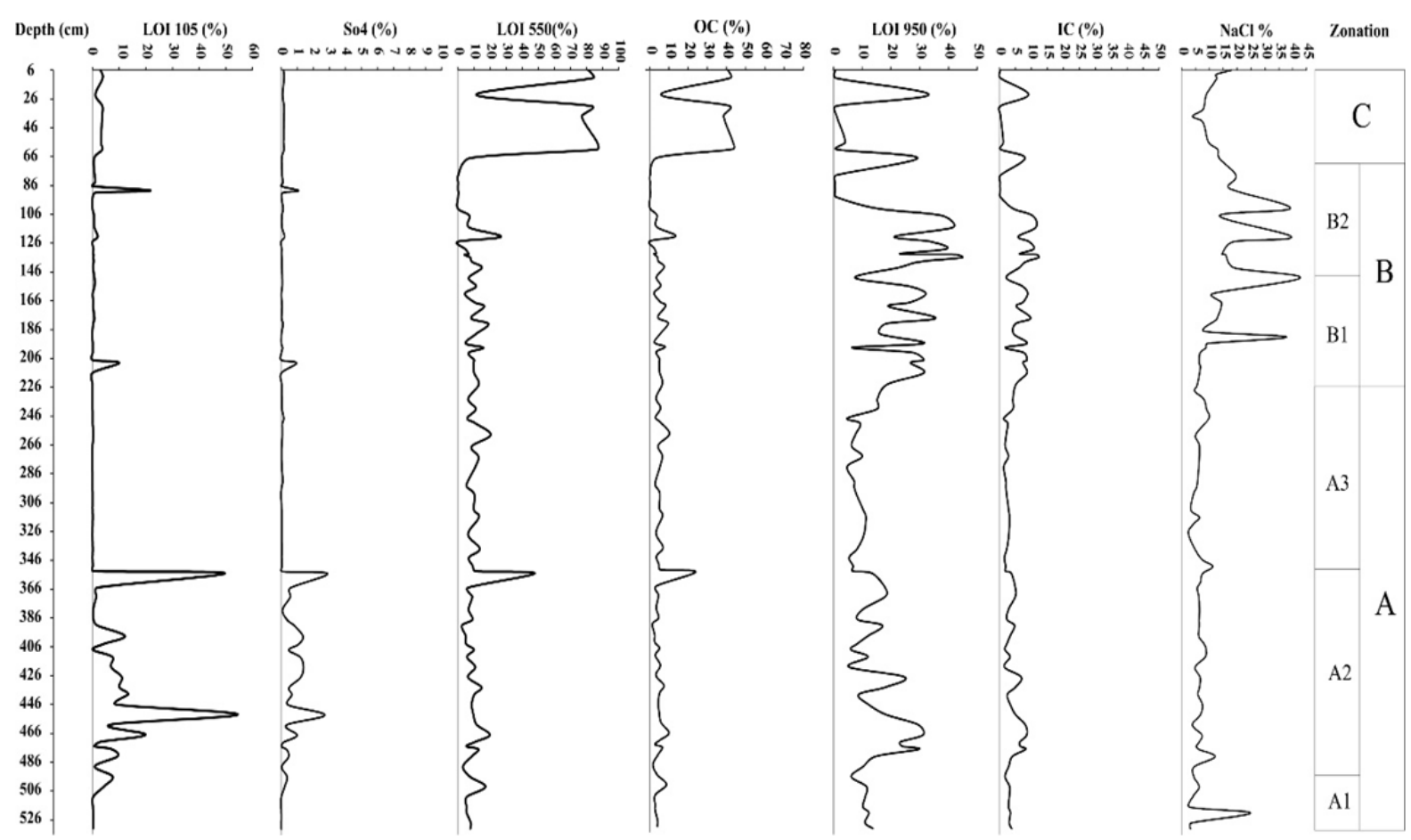

Figure 5. The changes of LOI (\%) in $105^{\circ} \mathrm{C}, 550^{\circ} \mathrm{C}$ and $950^{\circ} \mathrm{C}$ and is measured variations in the whole core of Sulfate calcium ( $\mathrm{SO}_{4} \%$ ), organic carbon (OC) \% and inorganic carbon (IC) \%. This Variations is categorized to afew Zones and Subzones

\section{Discussion}

A study on the recent evolution of this lake's hydrochemistry indicates that it's water chemistry has changed from a $\mathrm{Mg}-\mathrm{SO}_{4}-\mathrm{Cl}$ type in 1970 to a $\mathrm{Na}-\mathrm{Mg}-\mathrm{Cl}-\left(\mathrm{SO}_{4}\right)$ type (Lak, 2007; Fayazi et al., 2007). This means that given persistence of current input water with the chemistry of $\mathrm{HCO} 3<<\mathrm{Ca}+\mathrm{Mg}$, the lake brine evolution will lead to a $\mathrm{Ca}-\mathrm{Na}-\mathrm{Cl}$ or $\mathrm{Na}-\mathrm{SO}_{4}-\mathrm{Cl}$ brine type in the future. This is because of the recent decrease in lake volume which is a decrease in precipitation and an increase in ground water exploitation (Djmali et al., 2008). Punning et al. (2006) with study of lithology and granolometry of Martiska Lake short surface cores are found; changes in grain size parameter and capacity of mineral deposition was occurred during progredation and retrogradation lake which are reflected lake water level changes. They introduced three phase for sedimentary processes: 1 . The beginning of retrogradation since of 1960. 2. The minimum lake water level from 1992-1988 BC. 3. The progradation since 1992 as yet (Djamali et al., 2008). Magnetic susceptibility of soils and sediments and its variations are the results of the concentration and behavior of magnetic and diamagnetic minerals (Thompson \& Old field, 1986). It should be noted that in the arid regions, the effect to slight amount of gypsum and carbonates should calculate organic matter and magnetic susceptibility measurements that obtained to take into account, through organic matter and magnetic susceptibility calculation.

According to Ellwood et al. (2006) in general an increase in the amount of calcium carbonate and organic compounds in the sediment factor reduce the magnetic sucseptibility. The magnetic susceptibility of marine sediments clastic and biogenic act in opposition manner. According to them, since the biogenic elements are diamagnetic and have low and negative magnetic susceptibility, the classic sediments control the magnetic susceptibility. This phenomenon can usually control clastic processes in the marine environment, where the sediments modify the magnetic susceptibility.

Shahkarami et al. (2009) after studying sediment cores from the southern coast of Caspian sea found that, the size of the deposits is closely related to changes in magnetic susceptibility. The highest levels of magnetic susceptibility is partly based on sedimentary layers, containing great amount of silt where the percentage of fine great sediment (clay) lead to low levels of magnetic susceptibility.

The characteristics of the sediments that form a playa are controlled by the sedimentary processes acting on the playa (Langer \& Kerr, 1966; Last, 1980). Playas generally contain fine-grained clastic sediments such as clay or silt and non-clastic materials such as evaporites (Cooke \& Warren, 1973). Last (1984) defined four main types of 
deposits found in playas. The first type of deposits is very soluble evaporites such as gypsum and calcite which may also form during evaporation or early diagenesis. The other type of deposits is allochthonousor clastic inorganic materials which is transported into the playa by runoff, wind and maybe shoreline erosion on the high level lake water.

Most of the researchers believe that in continenta environments, sediments of playas and closed-basin lakes contain the best records of past hydrochemical, hydrological and climatic variations. Carbonate sediments are formed in lakes in temperate regions. Carbonates, sulfates (Gypsum \& Anhydrite) and rock salt (Halite) are formed by an increase in temperature and salinity (Moussavi, 2012).

As a result of study of evaporite in the lake Mahalou showed: Two conditions for the formation of gypsum deposits have been prepared in this sequences which include the first most average of gypsum (So4) which is $1.12 \%$ in the $510-360 \mathrm{~cm}$ dept (A2 sub zone). Gypsum is generally seen at permanent salt lakes. However, most gypsum is formed in oxygen-free waters and is consumed by sulfate-reducing bacteria at Lake Floor (Neev \& Emery, 1967).

Thus there is a permanent lake in this phase. It doesn't seem that there is no destruction of the vast majority of the formed gypsum (So4) by sulfate rebirth bacteria. Therefor this is the most important phase from the aspect of gypsum (So4) forming and lake drying.

The secondary maximume of gypsum (So4) is $1.09 \%$ in the $94 \mathrm{~cm}$ depth (B2 sub zone) and 1\% in the $214 \mathrm{~cm}$ depth (B1 sub zone).

These two horizons of gypsum (So4) forming are short term incidents and unstable. In the gap between incidents, there is increase of $\mathrm{NaCl}$ with extreme changes of frequency that show fluctuating water level of lake to form lake developing and constant dryness. Zone $\mathrm{b}$ is the maximum development of lake concerning fluctuation of salt as developing line of lake along with remarkable increase of $\mathrm{NaCl}$. The salt zone developed in mentioned horizon from farther part of the sampling area. In most of cases gypsum forms in silt facieses and shapes in depth of $94 \mathrm{~cm}$ from the surface in sandy silt faces. In this horizon saltiness is \%30 but organic and non-organic carbonates are zero.

\section{Conclusion}

In hot and humid climates where rainfall is high and a high volume of clastic sediments transfer into lakes. The suspended fine-grained sediments (silt and clay) deposit in a low energy environment in such circumstances. The past environmental changes can be found by examining the size of the grain concerning given close relationship between grain size and precipitation changes. There is a direct link between evaporate formation and lake level fall. The changes in evaporate deposits in the sedimentary sequence represent concentration oscillations of the water level at different stages in Maharlou lake. Accordingly change in the sediment layers indicate the level of evaporations. Vertical changes in sedimentary faces of the lake Maharlou core include:

1. There is not diversity of sediment grain size in the core. Rainfall fluctuations in zone A and C are low. But Rainfall fluctuations in zone B are high.

2. Magnetic susceptibility level is directly related to the silt layer thickness. But also it has opposite relation with the layers of organic sediments' abundance.

3. Conditions are more appropriate to form halite and carbonate deposits concerning lower amount of gypsum for inorganic carbonate and $\mathrm{NaCl}$.

4. With respect to Walter law and formation of carbonates, sulfate, and halite respectively from the edge to the center of the bull's eye facies make changes in the shoreline as follow:

a. In sub-zone A1 lake water level shows slump indicating sharp decrease of the water level and also there is a sharp increase of halite value.

b. Sub-zone A2 is the face of gypsum $\left(\mathrm{SO}_{4}\right)$ formation with minor fluctuations in salt and inorganic carbon. This sub-zone indicates of the water level.

c. The highest lake water level fluctuations had occurred in zone B revealing the formation of halite and calcium carbonate. This horizon is a special incident.

d. In zone $\mathrm{C}$ there is reverse relation between inorganic carbon trend and organic carbonate. Halite trend is decreasing from the beginning of the zone up to the middle. But the trend is increasing from the middle of the zone to the surface of the core. 


\section{References}

Battarbee, R. W. (1999). Palaeolimnological approaches to climate change, with special regard to the biological record. Quaternary Science Rev, 19, 107-124. Retrieved from http://www.paleo-ecology.com/UploadFiles/2012-07/paleo- ecology/2012072114091963811

Blott, S., \& Pye, K. (2001). Gradistat: A Grain size distribution and statistics package for the analysis of unconsolidated sediments. Earth Surf. Process. Landforms, 26, 1237-1248. Retrieved from http://www.geo.mtu.edu/ raman

Bowler, J. M. (1986). Spatial variability and hydrologic evolution of Australian lakes basins. Paleogeogr Paleoclimatol Paleoecol, 54, 21-41. Retrieved from http://www.ga.gov.au/corporate_data/79059/79059

Chao, L., Zicheng, P., Dong, Y., Weiguo, L., Zhaofeng, Z., Jianfeng, H., \& Chenlin, C. (2009). A lacustrine record from Lop Nur, Xinjiang, China: Implications for paleoclimate change during Late Pleistocene. $J$ Asian Earth Science, 34, 38-45. Retrieved from https://pubs.er.usgs.gov/publication/70032907

Cooke, R. U., \& Warren, A. (1973). Geomorphology in deserts. University of California Press, Berkeley, USA.

Crowley, J. K., \& Hook, S. J. (1996). Mapping playa evaporite minerals and associated sediments in Death Valley, California: with multispectral thermal infrared images. Journal Geophysics Research, 101, 643-660. Retrieved from http://onlinelibrary.wiley.com/doi/10.1029/95JB02813

Darvishzadeh, A. (1991). Geology of Iran (in Persian). Nashre Danesh Emroz Publisher. Tehran, Iran.

Djamali, M., De Beaulieu, J. L., Miller, N. F., Andrieu,V., Ponel, P., Lak, R., Sadeddin, N., ... Fazeli, H. (2008).Vegetation history of the SE section of the Zagros Mountains during the last five millennia; a pollen record from the Maharlou Lake, Fars Province, Iran. Veget Hist Archaeobot, 18, 123-136.

Dumas, D., Mietton, M., \& Humbert, J. (2003). Le fonctionnement hydroclimatique de la cuvette lacustre de Maharlou (Iran). Se'cheresse, 14(4), 219-226. $\quad$ Retrieved from https://www.researchgate.net/publication/280787378.

Ellwood, B. B., Garcia Alcalde, J. L., Hassani, A., Hladil, J., Soto, F. M., Truyols Massoni, M., ... Koptikova, L. (2006b). Stratigraphy of the Middle Devonian boundary: formal definition of the susceptibility magnetostratotype in Germany with comparisons to sections in the Czech Republic, Morocco and Spain. Elsevier, Tectonophysics, 418, 31-49. Retrieved from https://www.researchgate.net/publication/222884460

Enzel, Y., \& Wells, S. G. (1996). Extracting Holocene paleohydrology and paleoclimatology information from modern extreme flood events. An example from southern California: Geomorphology, 19, 203-226.

Evans, J. P., Smith, R. B., \& Oglesby, R. J. (2004). Middle East climate simulation and dominant precipitation processes. International Journal of Climatology, 24, 1671-1694. Retrieved from https://www.interscience.wiley.com

Farpoor, M. H., \& Krouse, H. R. (2008). Stable isotope geochemistry of sulfur bearing minerals and clay mineralogy of some soils and sediments in Loot Desert, Central Iran. Geoderma, 146, 283-290. Retrieved from https://faculty.unlv.edu/buckb/scanned\%20pfd/Farpoor08

Farpoor, M. H., Neyestani, M., Eghbal, M. K., \& Esfandiarpour Borujeni, I. (2012). Soil-geomorphology relationships in Sirjan playa, south central Iran. Geomorphology, 138, 223-230. Retrieved from https://www.deepdyve.com/lp/elsevier/soil-geomorphology-relationships-in-sirjan-playa-south-central-iran0ZeQ3yOxa4

Fayazi, F., Lak, R., \& Nakhaei, M. (2007). Hydrogeochemistry and brine evolution of Maharlou Saline Lake, southwestern of Iran. Carbonates Evaporites, 22, 34-42.

Gierlowski, K. E., \& Kelts, K. (1994). Global geological record of Lake Basins. Cambridge University Press, 427. Retrieved from http://eprints.ucm.es/12566/1

Holliday, V. T., Hovorka, S. D., \& Gustavson, T. C. (1996). Lithostratigraphy and geochronology of fills in small playa basins on the Southern High Plains. Geological Society of America Bulletin, USA, 108, 953-965. Retrieved from http://www.argonaut.arizona.edu/articles/holliday_etal1996.pdf

Krinsley, D. B. (1970). A geomorphological and paleoclimatological study of the playas of Iran. United States Geological Survey: U.S, Department of Interior, Washington D.C, U.S.A.

Krinsley, D. B. (1972). Dynamic processes in the morphogenesis of salt crusts within the Great Kavir, northcentral Iran. In: Proceedings of 24th International Geological Congress, Montreat, 167-174. Retrieved 
from https://books.google.com/books?id=DwQlA 24th+International+Geological+Congress

Lak, R. (2007). Sedimentology, hydrochemistry and brine evolution of Maharlou Lake (in Persian). (Unpublished PhD's thesis). Teacher Training University, Tehran

Langer, A. M., \& Kerr, P. F. (1966). Mojave playa crusts. physical properties and mineral content. Journal Sediment Petrol, 36, 377-396. Retrieved from http://jsedres.sepmonline.org/content/36/2/377

Last, W. M. (1980). Sedimentology and postglacial history of Lake Manitoba. (Unpublished PhD's thesis). University of Manitoba, Winnipeg.

Last, W. M. (1980). Sedimentology of a saline playa in the northern Great Plains. Canada Sedimentology, 36, 109-123. Retrieved from http://www.readcube.com/articles/10.1111\%2Fj.1365-3091.1989.tb00823

Last, W. M. (1983). Sedimentology of playa lakes of the northern Great Plains. Can Journal Earth Sciences, 21, 107-125. Retrieved from http://home.cc.umanitoba.ca/ mlast/publications/page10/assets/1984cjes.

Liu, Q., Roberts, A. P., Larrasoaña, J. C., Banerjee, S. K., Guyodo, Y., Tauxe, L., \& Oldfield, F. (2012). Environmental magnetism: principles and applications. American Geophysical Union: Reviews of Geophysics, 50. Retrieved from http://people.rses.anu.edu.au/roberts_a/AR_Publications/150.\% 20Liu\%20et\%20al.\%202012

Moussavi Harami, R. (2010). Sedimentology, (12nd Ed.). Press Astan Quds Razavi publishing Behnashr company. Tehran, Iran.

Nazemosadat, M. J., \& Cordery, I. (2000). On the relationships between ENSO and autumn rainfall in Iran. International Journal Climatology, 20, 47-61. Retrieved from $\mathrm{http} / /$ www.onlinelibrary.wiley.com/doi/10.1002/(SICI)1097-0088(200001)20:1<47:AID-JOC461>3.0.CO;2 $-\mathrm{P}$

Rahimpour Bonab, H., \& Abdi, L. (2012). Sedimentology and origin of Meyghan lake/playa deposits in Sanandaj-Sirjan zone, Iran. Carbonates Evaporites, 27, 375-393. Retrieved from http://link.springer.com/article/10.1007\%2Fs13146-012-0119-0

Rahimpour Bonab, H., \& Alijani, N. (2003). Petrography diagenesis and depositional model for potash deposits of North Central Iran, and use of bromine geochemistry as a prospecting tool. Carbonates Evaporites, 18, 19-28. Retrieved from http://gsi.ir/Images/webexploration/paper/garmsarceminar

Rahimpour Bonab, H., \& Kalantarzadeh, Z. (2005). Origin of secondary potash deposits; a case from Miocene evaporites of NW Central Iran. Journal Asian Earth Science, 25, 157-166. Retrieved from http://www.freepaperdownload.us/1750/Article4778326.htm

Rahimpour Bonab, H., Shariatinia, Z., \& Siemann, M. G. (2007a) Origin and geochemistry of Miocene marine evaporites associated with red beds, Great Kavir Basin. Central Iran, Geology Journal, 42, 37-54. Retrieved from http://ebooks.geoscienceworld.org/content/evaporites-through-space-and-time

Rahimpour Bonab, H., Shariatinia, Z., \& Siemann, M. G. (2007b). Role of rifting in evaporite deposition in the great Kavir Basin, Central Iran. Geological Society of London. Sp. Pub., 285, 263-279. Retrieved from http://sp.lyellcollection.org/content/285/1/69

Santisteban, J. I., Mediavilla, R., Pamo, E. L., Dabrio, C. J., Zapata, M. B. R., Garcia, M. J. G.,... Martinez, P. E. (2004). Loss on ignition: a qualitative or quantitative method for organic matter and carbonate mineral content in sediments? Journal of Paleolimnology, 32, 287-299. Retrieved from http://eprints.ucm.es/10760/1/2004_1

Shahkarami, S., Rahimpour Bonab, H., Alizadeh Ketek Lahijani, H., Leroy, S., \& Shahhosseini, M. (2009). Sea level change interpration of Caspian sea by using magnetic susceptibility data of bottom sediments. Sedimentary facies, 2(1), 41 -59. Retrieved from http://en.journals.sid.ir/ViewPaper.aspx?ID=207076

Shahrabi, M. (1995). Geology of Iran (Sea and Lakes of Iran), (2nd Ed.). Geological Survey of Iran (in Persian), Tehran, Iran.

Sinha, R., Smykatz Kloss, W., Stuben, D., Harrison, S. P., Berner, Z., \& Kramar, U. (2006). Late Quaternary paleoclmatic reconstruction from the lacustrine sediments of the Sambhar playa core, That Desert margin, India. Paleogeogr Paleoclimatol Paleoecol, 233, 252-270. Retrieved from http://home.iitk.ac.in/ rrsinha/Publication/2006_Sambhar_Paleo3

Spencer, R. J., Baedecker, M. J., Eugster, H. P., Forester, R. M., Goldhaber, M. B., Jones, B. F., ... Bowser, C. J. 
(1984). Great Salt Lake, and precursors, Utah: the last 30,000 years. Contrib Miner Petrol, 86, $321-334$. Retrieved from http://edupaper.ir/Pages/Download.aspx?filename=springer110029b8-131120151212122031.pdf\&Core $=$ Core 17

\section{Copyrights}

Copyright for this article is retained by the author(s), with first publication rights granted to the journal.

This is an open-access article distributed under the terms and conditions of the Creative Commons Attribution license (http://creativecommons.org/licenses/by/3.0/). 